\title{
TRINITY IN THE QUR'AN: A HISTORICAL ACCOUNT
}

\author{
Media Zainul Bahri \\ Syarif Hidayatullah State Islamic University (UIN) Jakarta \\ zainul.bahri@uinjkt.ac.id
}

\begin{abstract}
This article focuses on historical accounts about the different views between the Qur'an in the period of its formative in the 7th century and the official Christian church since the 3rd century AD. Theologically, what is meant by the Trinity in the Qur'an is a belief in three Gods: God (Allah), Jesus (Isa), and Mary, as the three independent Gods, while the Christian belief confirms that God, Jesus and the Holy Spirit (not Mary) are one God, not three independent gods. The only one is in "three ways of being". Historically, the explanations of Olaf Schumann, Parrinder, Kurt Aland, Anton Wessels, and Fazlur Rahman, indicate two important things. First, the Christians in Arabia and whom Muhammad met in Mecca and Medina were dominated by the Nestorians who emphasized the humanity of Jesus and the One Almighty God. That is why the Qur'an sharply criticizes the system of the Trinity and the divinity of Jesus and Mary. However, both Schumann and Parrinder believe the Qur'an's criticisms of Christianity are misdirected, in a sense not to the official Christian Trinity doctrine. The starting point was wrong and so at last. Second, since Mecca is a very international, there are probably many Christian people or communities with different streams. But, as Schumann stated, they were merchants, not theologians. Schumann, Parrinder and many Christian and Jewish scholars agreed that the Christian and Jewish communities in the time of the prophet subjected to criticism of the Qur'an are sects deviating from the legitimate doctrine. Moreover, when the prophet lived, there had been no acceptable philosophical explanations of the great thinkers concerning the doctrine of both Jewish and Christian monotheism to those who were thoughtful. In other words, the prophet only heard and received any information about the theology of both Christian and Jewish from ordinary people or priests who were not master at esoteric knowledge.
\end{abstract}

Keywords: Trinity, official Christian church, Nestorian.

\section{Introduction}

One must be careful that the Qur'an verses of the Trinity differ from the official Trinitarian doctrine of the Christian church since the 3rd century AD. What is meant by the Trinity in the Qur'an is a belief in three Gods: God (Allah), Jesus (Isa), and Mary, as the three independent Gods (see sura al-Maidah: 116). It is true when the Qur'an states that "Indeed, the truth deny they who say, "Behold, God is the third of a trinity..." (al-Maidah: 74). The word „third" in that verse indicates there is a first and a second God, each of which is independent. However, the problem is that the doctrine of the Trinity confirms that God, Jesus and the Holy Spirit (not Mary) are one God, not three independent gods. The only one is in three ways of being. For Ward, most Western theologians have said that there is only one center of consciousness and will in God, not three. True, there are three ,persons ${ }^{\text {ee }}$ in one „substance should not be understood as an individual rational agent, with its own independent will. For this view, the word ,persone in its modern English is very misleading, and should be understood as a "way of beinge, not as separate individual agent (Keith Ward, 1995: 81- 82). In other words, the Trinity is not about "the number of Gods", but "the wisdom of God". This crucial problem of this "Christian mystical" is always 
misunderstood by non-Christians who embrace "rationalistic theology" such as Islam and Judaism. Therefore, according to the Christian scholars (as well as its theologians), the Qur'an's criticism is a very simple theological view as understood by Arabs and Muslims in the $7^{\text {th }}$ century, and is not addressed to the official Christian/Church doctrine as I discuss below.

This article uses a historical approach by describing historical records from Christian and Muslim historians. The historical record will be matched by the Qur'an statement, so it will produce valid historical data and close to empirical truth.

\section{Historical Accounts}

This article will reveal the historical matters about the different views between the Qur'an and the official church on the Trinity in the 7th century, the period of the Qur'an formative. According to the history of Christianity, around Hijaz--during the life of Muhammad--there are several deviant Christian sects that believed in God as Father, the Son, and Mary. In this regard, Schumann believes that, historically, in Africa and Arabian peninsula, there were some similar beliefs to worship the Jesus Christ and his mother, Mary, together. For instance, the ancient Egyptians believed in Horus, the holy son of Osiris and Isis who became a worshiped Pharaoh. According to Schumann, such belief has had influenced some Christian Egyptians living in Mecca or Arabia on their remembrance of Jesus and Mary (Olaf Schumann, 1993: 195). Geoffrey Parrinder, a Professor of Comparative Religion at the University of London, said that in the early centuries of $\mathrm{AD}$, some Christian groups in the Peninsula of Arabia called themselves as the Antidicomarianite, a sect that denies the perpetual virginity of Mary. Its followers then committed to cult her by wearing inappropriate dress. There were also the Collyridians, a group of Arabian women in the 4th of the century adored Mary by presenting her with a special kind of bread (collyrida) intended as sacrifice as was for Goddess Earth's offering. The cult is exactly the same as idol worship practices. A Christian theologian, Epiphanus, calls such practices as a deviation from the original Christian tradition. According to him, the Trinity: the Father, the Son, and the Holy Spirit must be worshiped, but should not be Mary. For Parrinder, the Qur'an's criticism of the cult of Mary is likely to be addressed to the deviant sect, and the Qur'an actually affirms the urgency of Mary as the woman chosen by God to give birth to Jesus (Parrinder, 1996: 135).

It is also important to know that the Christian faith embraced by the King of Negus in Abyssinia, Ethiopia, is a Christian that sanctifies Mary. She was praised as God for being the one who gave birth to the Lord Jesus. Husain Haekal notes at that time in Abyssinia, there was a dispute between the group who cult to Mary and the ones that worship Jesus. There is also a record that Mary is cultured but not worshiped because she is the holy virgin who gave birth to Lord Jesus. The Prophet Muhammad knew well about the King of the Negus and ordered the early Muslims who were pursued and tortured by the Quraysh to emigrate (hijra) to Abyssinia. The Negus King welcomed them warmly and placed them safely (Haekal, 1947: 156-57).

Both Schumann and Parrinder agreed, albeit with different historical accounts, that there were sects and forms of Mary worship in the early centuries of AD until to the time of Muhammad. Furthermore, Schumann argues that it is also necessary to look at, historically, the relationship of Muhammad with the Christianity and the Lord Jesus. Yet, it is not easy to find a definitely answer about it. According to Schumann, there were Christian traders in Mecca who were very likely to discuss with Muslims, or tell heroic stories, either in the afternoon or at night, including religious heroes. There are also records about the existence of Christian workers or slaves who worked for the 
household of Muhammad and his friends. Other records mention that Muhammad was witnessing the social and religious life of the Christians while he was trading up to Syria (Schumann: 191-92).

According to the history of early Christianity, the Christian communities living and thriving in the Middle East, especially in Syria, are Nestorians. The are Nestorius followers who are also the Origenese and Arius successors. The Nestorian is a sect which emphasizes more on the One Almighty God and the human nature of Jesus. Despite they differ and separate from the Roman (Western) Christian theology, this Eastern Christians still believe in the concept of Jesus as the Son of God in the sense of the unity of man-God as a compound (as in a marriage), not as understood by Western Christians (Anton Wessels, $2004: 5$ ).

According to Anton Wessels, Christianity was not a stranger to Arab people. Even before the arrival of the Nestorians, in $225 \mathrm{AD}$, there was a diocese in Berth-Katraye, Qatar. The Christianity has spread to the tribes of Himyar, Ghassan, Taghlib, Tanukh, Tayy, and Quda'a, long before the arrival of Islam. There was an Arabian Christian queen named Maria who once invited the bishop of Moses to live in her country. The Ghassanids under Byzantine kingdom were monophysitists, while the Lakhmida of Hira relating to Persia were Nestorians (Wessels: 33).

In the $5^{\text {th }}$ century, one of the five dioceses in Arabia is the diocese of Hira under the Nestorian Archbishop led by Kashkar. Nestorian diocese was also existed in Bahrayn, Qatar and Oman. There are also churches in San'a, such as a cathedral established by Abrahah al-Asman- Aden and Dhofar. A famous Christian mystic from the mid-seventh century, Isaac of Ninewe, was born in Qatar. At the end of the sixth century, there was a growing Christian community in Yemen. Usually, Christian Arabs who are adherents of the Eastern Church, automatically become Nestorian, but there are also those under the influence of Jacobite. One assumes that the monk Buhaira, who allegedly met the prophet Muhammad in his teenage years, was a Jacobite. However, according to a more valid source, he was a Nestorian since Syria is the center of Nestorian (Wessels: 33).

The description of the Christian communities in Arabia explains that Christians had extensively spread, long before Islam. There were many Christians who were born and lived in the Arabian Peninsula, or at least made contact with Arabs for business purposes since Mecca was a harbor and metropolitan city to be visited by many nations with different religions and cultures. Not only the Nestorian in the north, but also many other streams, including Christians in the south (Yemen), in the west (Egypt and African countries), and Those who follow the church of Rome and Constantinople. They came and stopped by or settled in Mecca for business purposes. Fazlur Rahman, a professor of the Chicago University and a Muslim intellectual from Pakistan, agrees with the view that prior to Islam, there has already been a relationship among Arabs with people of the Book (Ahl al-Kitab), especially Jews. In this context, Muhammad has received the correct information from Christians about the Trinity and Jesus as the incarnate of God. To Rahman, it is very difficult to accept the idea that Muhammad was misunderstood about the doctrine of incarnation (Rahman, 1989: 155-162).

According to Rahman, the particular issue on the Trinity and the divinity of Jesus that understood by Muhammad is in accordance with the Qur'anic criticisms over the Christian theology. For the Qur'an, the faith in the Trinity and believe in Jesus-who was born as human being and has limitations--as God, is an impossible, unreasonable and unforgivable. Referring to the Qur'an, Rahman calls this Christian doctrine as "extremism in faith" (Rahman: 168). However, if reading the Qur'ans 
criticism about this matter, Rahman"s assumption that Muhammad has received the valid information about the Trinity is incorrect because the Qur'an does not excoriate on the official Trinity recognized by the Roman and Constantinople church. Still, Rahman is right about the Christians who believe Jesus as God.

Having the historical explanations of Schumann, Parrinder, Kurt Aland, Wessels, and Rahman, there are two important things I would say. Firstly, the Christians in Arabia and whom Muhammad met in Mecca and Medina were dominated by the Nestorians who emphasized the humanity of Jesus and the One Almighty God. If that so, why does the Qur'an sharply criticize the system of the Trinity and the divinity of Jesus and Mary? There are two important assumptions that should be put forward: (1) the disapproval of the Qur'an may corroborate the Nestorian criticism over the concept of the Trinity as adopted by the Roman church; (2) it means that there are non-Nestorian communities and other Christian sects, who interacted with Muhammad, deemed to deviate from the official church, especially in the West (Africa) where one of its teachings is to worship Mary. In this context, both Schumann and Parrinder believe the Qur'an's criticisms of Christianity are misdirected, in a sense not to the official Christian Trinity doctrine. The starting point was wrong and so at last.

Secondly, since Mecca is a very international, there are probably many Christian people or communities with different streams. One of them having faith in the divinity of Jesus (Athanasius school), had business activity in Mecca and contacted with the prophet Muhammad. But, as Schumann stated, they were merchants, not theologians. Therefore, this is a main reason for the revelation verses that prominently criticize the Christian trinity. There are also some Islamic literatures that point out about the Prophet"s encounter with Christians and Jews. For example, the prophet"s relationship with Waraqah Ibn Naufal, cousin of Khadijah, the first wife of the prophet. Waraqah was a Nestorian priest who allegedly translated some of the Bible into Arabic. The history tells us that when Muhammad accepted his first revelation, Waraqah, based on his knowledge, believed that Muhammad received the Great Namus (revelation) as Moses had received. He said that if he lived any longer, he will support the religion of Muhammad, but he died soon (Haekal: 135-37).

There are no evidences show that Muhammad has ever discussed on theological issues with Waraqa or Buhaira, whom Muhammad met in his youth. Other records indicate that Muhammad was visited by the Christians of Najran (a place around Medina) under the leadership of Bishop Abu al-Harithah Ibn Alqama and they discussed about theology. Even the prophet allowed them to worship at his mosque. Couple days after the discussion, there was tidings that two Christian leaders, alSayyid and al-Aqib, came back to Madinah to embrace Islam (Haekal: 239).

Dealing with the prophet's relationship with the Jewish, Shahih Bukhari narrates that Aisha, the second wife of the prophet, often chatted and discussed with the Jewish women at the prophet's house. The prophet sometimes involved to the discussion when it came to religious matters. The Jewish woman who came to the prophet's house was sometimes alone, sometimes more than one. The prophet also had a friendship with Mukhairiq, a Jewish priest who was proficient in the Torah and wealthy among the Quraidah tribe. There was a strong possibility of the prophet often having discussion with him over religious issues. He died fighting on the side of the prophet and gave his entire wealth for the Muslims concerns. Regarding this remarkable goodness, the Prophet commented, "Mukhairiq is the best of the Jews" (Musthafa Yaqub, 1999: 39-40). One who reads Husain Haekal's history of the prophet, will find the record of bitter words between the prophet and the JewishChristian leaders in Medina on matters of faith. The Jews proclaimed that Ezra (Uzair) 
was the son of God while Christians still believed in the Trinity: Jesus, Mary, and Father are gods. Such models of conviction have grounded the Qur'anic criticism over the Trinity.

\section{Conclusion}

The Qur'an has no mistaken, but again Schumann, Parrinder and many Christian and Jewish scholars agreed that the Christian and Jewish communities in the time of the prophet subjected to criticism of the Qur'an are sects deviating from the legitimate doctrine. Moreover, when the prophet lived, there had been no acceptable philosophical explanations of the great thinkers concerning the doctrine of both Jewish and Christian monotheism to those who were thoughtful. In other words, the prophet only heard and received any information about the theology of both Christian and Jewish from ordinary people or priests who were not master at esoteric knowledge.

According to Ameer Ali, the deviation of the Christian idea lasted for a long time. Besides the God of Jesus, the practice of the Trinity, and believing Mary as a God, also there has been myths and superstitions surrounded around. These were emerging the worship of Mary and the statues which then made deviations even getting worse. Muhammad was sent to counter such deviations and ignorance (Ali, 1953: 143). This means Muhammad came to Jewish and Christian people who are deviated from the official doctrine as formulated in the Council of Nicea in 325 AD.

Accordingly for Schumann, the Qur'an accounts of Jesus or Mary do not correspond to the Old or New Testament which may not have been translated into Arabic, either in part or in whole. Furthermore, the details of the Qur'an versions are similar to those commonly found in Christian or Jewish apocrypha, i.e. uncanonized books and those from ordinary Christians. In other words, there were already popular theology books or at least a popular understanding of Christianity, which are not the work of Christian theologians due to many innacuracies teachings. In fact, the books often contain unfinished theological problems, and emphasize more on exciting and magical things to hear than the true theological meanings (Schumann: 191-92).

\section{References}

Aland, Kurt. 1985. A History of Christianity: From Beginnings to the Treshold of the Reformation, terj. James L. Schaaf. Philadelphia: Fortress Press.

Ali, Syed Ameer. 1953. The Spirit of Islam: A History of the Evolution and Ideals of Islam. London: Christopers.

Haekal, Muhammad Husayn. 1947. Hayat Muhammad. Kairo: Mathabah Mishriyyah.

Parrinder, Geoffrey. 1996. Jesus In The Qur'an. Oxford: One World.

Rahman, Fazlur. 1989. Major Themes of the Qur 'an. Minneapolis, USA: Bibliotheca.

Schumann, Olaf. 1993. Pemikiran Keagamaan Dalam Tantangan. Jakarta: Gramedia Widiasarana Indonesia.

Ward, Keith. 1995. Christianity: A Short Introduction. Oxford: One World.

Wessels, Anton. 2004. Arab dan Kristen: Gereja-gereja Kristen di Timur Tengah, trans. Taty S.L.Tobing-Kartohadiprojo. Jakarta: BPK Gunung Mulia. 